

\title{
MENINGKATKAN KEMAMPUAN BELAJAR KOPSTAND MELALUI METODE LATIHAN SISWA KELAS X SMA NEGERI 4 AMBON
}

\author{
Semmy Leuna ${ }^{1}$ Albertus Fenanlampir ${ }^{2}$ \\ semuelleuna@gmail.com,
}

\begin{abstract}
ABSTRAK
Penelitian ini untuk mengetahui metode merupakan barometer untuk mencapaian tujuan pembelajaran" untuk itu penulis ingin sekali melakukan penelitian mendalam tentang meningkatkan kemampuan belajar kopstand melalui metode latihan siswa kelas $x$ sma negeri 4 ambon. Metode penelitian ini merupakan penelitian tindakan kelas. Subjek dalam penelitian ini adalah siswa kelas $x_{1}$ sma negeri 4 ambon yang berjumlah 30 orang. Berdasarkan nilainilai dari siklus I dan siklus II dapat disimpulkan untuk siklus I pembelajaran belum berhasil karena belum memenuhi standar ketuntasan $75, \%$. dari jumlah keseluruhan siswa baik dalam aspek kognitif, afektif maupun psikomotor. Pada siklus I pembelajaran sudah berjalan dengan baik, anak sudah antusias dalam pembelajaran akan tetapi siswa masih belum serius dalam mengikuti pembelajaran dan masih ada yang takut atau kurang percaya diri. Sedangkan pada siklus II nilai pembelajaran lebih meningkat karena adanya perbaikan dalam pembelajaran sehingga siswa mampu mencapai KKM $\geq 75$
\end{abstract}

Kata Kunci : belajar Kopstand, Metide Latihan,

\section{IMPROVING COPSTAND LEARNING ABILITIES THROUGH TRAINING METHODS CLASS X STUDENTS OF SMA NEGERI 4 AMBON}

\begin{abstract}
This research is to find out the method is a barometer to achieve the learning objectives. Therefore, the writer is eager to do an in-depth study on improving the learning ability of the Kopstand through the training method for the students of class $x$ SMA Negeri 4 Ambon. This research method is a classroom action research. The subjects in this study were 30 students of class $x 1$ public high school 4 Ambon. Based on the values of cycle I and cycle II, it can be concluded that for cycle I learning has not been successful because it has not met the completeness standard of $75 \%$. of the total number of students both in cognitive, affective and psychomotor aspects. In the first cycle, the learning has gone well, the children are enthusiastic about learning, but students are still not serious about taking part in learning and there are still those who are afraid or lack confidence. Whereas in cycle II the value of learning increased due to improvements in learning so that students were able to achieve KKM $\geq 75$
\end{abstract}

Keywords: learning Kopstand, Exercise Method, 


\section{Pendahuluan}

Pendidikan jasmani juga mengarahkan siswa supaya tumbuh dan berkembang secara harmonis dan seimbang. Sesuai dengan apa yang diungkapkan oleh (Afif, 2019) bahwa "Pendidikan jasmani pada hakekatnya adalah proses pendidikan yang memanfaatkan aktivitas fisik untuk menghasilkan perubahan holistik dalam kualitas individu, baik dalam hal fisik, mental serta emosional".

Menurut (Fuad \& Sudarso, 2014) bahwa pembelajaran olahraga adalah suatu porses yang dilakukan secarah sadar dan sistematis melalui berbagai kegiatan jasmani untuk memperoleh pertumbuhan jasmani, kesehatan dan kesegaran jasmani, kemampuan dan keterampilan, kecerdasan dan perkembangan watak serta kepribadian yang harmonis dalam rangka membentuk manusia Indonesia seutuhnya yang berkualitas berdasarkan pancasila. Selain mengubah perilaku pengguna, olahraga melalui aktivitas jasmani senantiasa mengupayakan untuk mencapai tujuan pendidikan itu sendiri.

Adapun ruang lingkup pendidikan jasmani meliputi aspek permainan dan olahraga, aktivitas pengembangan, uji diri/senam, aktivitas ritmik, dan pendidikan luar kelas. Sehubungan dengan proses belajar mengajar senam, pada senam lantai Kopstand yang ada di SMA Negeri 4 Ambon pada kelas $X$ dengan metode mengajar yang digunakan seorang guru pendidikan jasmani ketika melaksanakan proses pembelajaran penjas, merupakan barometer untuk memajukan kualitas peserta didik dalam hal ini adalah siswa. Oleh karena itu, seorang guru penjas harus jeli dalam memilih, dan menetapkan, metode mengajar yang akan diimplementasikan serta dikemas dalam sebuah proses pembelajaran, sehingga siswa mampu memahami isi pesan berupa matari yang disampaikan.

Berdasarkan fakta empiris yang ditemui dilapangan, maka penulis menyimpulkan bahwa "Metode merupakan barometer untuk mencapaian tujuan pembelajaran" untuk itu penulis ingin sekali melakukan penelitian mendalam tentang "Meningkatkan Kemampuan Belajar Kopstand Melalui Metode Latihan Siswa Kelas X SMA Negeri 4 Ambon".

Menurut (Wuryantoro \& Muktiani, 2011)"Senam dengan istilah lantai, merupakan gerakan atau bentuk latihannya dilakukan di atas lantai dengan beralaskan matras sebagai alat yang dipergunakan”. Berdasarkan materi yang ada dalam latihan senam lantai, keterampilan tersebut di atas terbagi ke dalam unsur gerakan yang bersifat statis (diam ditempat) dan dinamis (berpindah tempat). Keterampilan senam lantai yang bersifat statis meliputi: kayang, sikap lilin, splits, berdiri dengan kepala, berdiri dengan kedua tangan dan lain sebagainya. Sedangkan keterampilan senam lantai yang bersifat dinamis meliputi; guling depan, guling belakang, guling lenting, meroda dan lain sebagainya.

Kemampuan adalah kompetensi mendasar yang penting untuk dimiliki siswa dalam mempelajari materi tertentu dalam suatu mata pelajaran di jenjang tertentu. Selain itu, guru juga hendaknya membantu siswa dalam proses pembelajaran agar siswa memiliki kemampuan untuk mengenal keterkaitan unsur-unsur dalam suatu objek. Lebih lanjut, (Wuryantoro \& Muktiani, 2011)).

Menurut (Winkel, 1996) menyatakan bahwa belajar adalah suatu aktivitas mental atau psikis yang berlangsung dalam interaksi dengan pengetahuan, pemahaman, ketrampilan, dan nilai sikap. Selanjutnya belajar 
ialah suatu proses usaha yang dilakukan seseorang untuk memperoleh tingkah laku yang baru secara keseluruhan, sebagai hasil pengalamannya sendiri dalam interaksinya dengan lingkungan.

Hasil belajar juga selalu merupakan wawasan, pemahaman, dan tidak hanya terbatas pada situasi dimana hasilitu diperoleh, tetapi dapat ditransfer atau digunakan dalam situasi-situasi lain. Selain itu, tujuan pengajaran yang merupakan hasil belajar juga mencakup rana kognitif, rana afektif dan ranah psikomotor. Rana kognitif adalah suatu kemampuan yang berhubungan dengan berpikir, mengetahu dan memecahkan masalah. Ranah afektif adalah suatu kemampuan yang berhubungan dengan sikap, nilai-nilai dan apresiasi. Sedangkan ranah psikomotor adalah suatu kemampuan yang berhubungan dengan ketrampilan motorik (Suyanto, 2006)

Menurut (Riwu, 2003) bahwa pendidikan jasmani adalah proses pendidikan yang melibatkan interaksi antara peserta didik dengan lingkungan yang dikelola melalui aktivitas jasmani secara sistematik menuju pembentukan manusia seutuhnya. Artinya dalam proses pembelajaran pendidikan jasmani guru harus mempertimbangkan keseluruhan kepribadian anak, sehingga pengukuran proses dan produk memiliki kedudukan yang sama penting.

Menurut (Daryusman et al., 2014) teknik dasar berdiri dengan kepala (Kopstand) sebagai berikut :

a. Berdiri tegak, kemudian letakkan kedua telapak tangan pada matras selebar bahu.

b. Letakkan dahi pada matras didepan kedua tangan. Letak dahi dan kedua tangan membentuk segi tiga sama sisi

c. Tarik kedua kaki ke atas, lurus dengan badan. Dengan begitu, berat badan betul-betul berada pada kedua tangan dan dahi,

d. Angkat panggul ke atas, bersamaan dengan kedua kaki terangkat lurus ke atas,

e. Pertahankan untuk beberapa waktu,

Turunkan pelan-pelan kedua kaki pada posisi semula.

Metode Latihan adalah metode mengajar dengan memberikan latihan secara berulang-ulang untuk menanamkan kebiasaan-kebiasaan tertentu, (Surlani et al., 2019). Pembelajaran dengan metode latihan adalah suatu cara yang memberikan kesempatan kepada siswa untuyk melaksanakan tugas-tugas setelah menerima penjelasan dan melihat peragaan/tugas gerak dari guru, serta siswa menerima umpan balik yang diberikan guru.

Guru berperan dalam mengambil keputusan sebelum latihan dimulai, siswa sebagai pengambil keputusan selama latihan berlangsung dan sesudah pertemuan keputusan ada ditangan guru, (Afif, 2019) Selanjutnya dikatakan bahwa dalam metode latihan, ada beberapa keputusan selama pertemuan berlangsung yang dipindahkan dari guru ke siswa. Penggunan satu metode pembelajaran untuk segalah tujuan pembelajaran tidak selalu efektif, Setiap metode pembelajaran mempunyai batas-batas kelebihan dan kelemahan, bukan saja terhadap tujuan tertentu tetapijuga terhadap situasi tertentu.

\section{Lokasi dan Waktu Penelitian}

a. Penelitian tindakan kelas (PTK) dilaksanakan pada SMA Negeri 4 Ambon.

b. Penelitian ini dilaksanakan dalam kurung waktu 1 (satu) bulan 


\section{Subyek Penelitian}

Subjek dalam penelitian ini adalah siswa kelas $X_{1}$ SMA Negeri 4 Ambon yang berjumlah 30 orang.

\section{Prosedur Penelitian}

Jenis penelitian ini adalah penelitian tindakan kelas (Clasroom Action Research). Dalam penelitian tindakan kelas ini, peneliti merencanakan melalui tiga siklus yaitu siklus I, II dan siklus

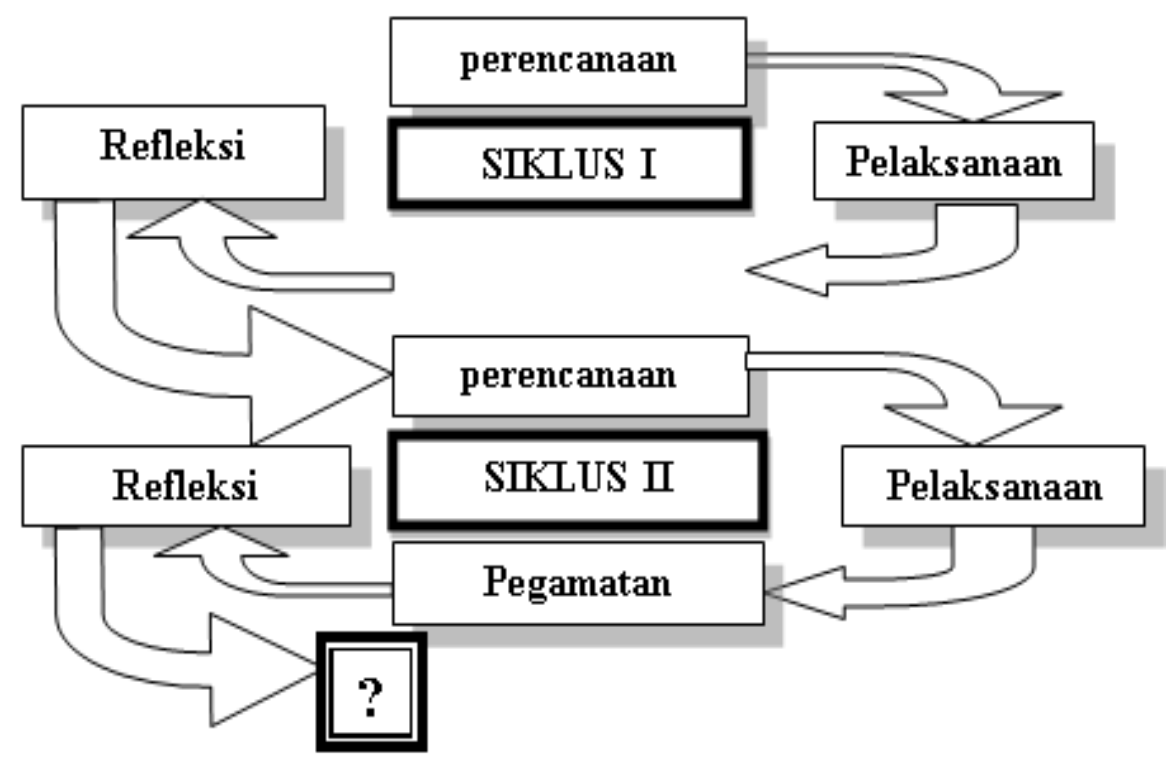

Gambar: Siklus Penelitian Tindakan Kelas.

(Arikunto, 2010)

Penelitian Tindakan kelas (PTK) ini di rencanakan tiga siklus, untuk mengetahui peningkatan hasil belajar kopstand pendidikan jasmani, olahraga dan kesehatan dengan menggunakan metode Latihan. Siklus terdiri dari empat langkah yaitu perencanaan, pelaksanaan tindakan, observasi dan refleksi. Secara oprasional prosedur penelitian tindakan kelas dapat di uraikan sebagi berikut:

Siklus I

1. Perencanaan

a) Penentuan waktu tindakan kelas

b) Penentuan kelas yang akan di beri tindakan

c) Perencanaan tindakan yang akan di berikan (materi kopstand)

d) Pembuatan RPP

e) Persiapan alat-alat yang di gunakan dalam pembelajaran

2. Pelaksanaan Tindakan

Menerapkan tindakan dengan mengacu pada RPP yang telah disusun,yaitu :

a. Pendahuluan

1) Siswa dibariskan, dihitung, dipimpin berdoa

2) Apersepsi 
3) Memimpin pemanasan

b. Kegiatan inti

1) Gerakan kopstand

2) Penilaian

3. Observasi

a) Mengamati proses pembelajaran

b) Pengisisan lembar observasi

c) Mendokumentasikan pembelajaran

4. Refleksi

Menganalisis data yang diperoleh dari lembar observasi, masukan dari teman (critical friends), guru penjas yang bersangkutan, dan kemudian dilakukan refleksi. Refleksi ini dilakukan untuk menilai tindakan yang telah diberikan. Selanjutnya mengadakan evaluasi tentang penelitian tindakan kelas, dengan cara berdiskusi tentang masalah yang muncul dalam pembelajaran.

Siklus II

1. Perencanaan

a) Konsultasi dengan guru pendidikan jasmani

b) Perencanaan tindakan kelas (materi kopstand)

2. Pelaksanaan Tindakan

Menerapkan tindakan dengan mengacu pada RPP yang telah disusun, yaitu:

a. Pendahuluan

1) Siswa dibariskan, dihitung, dipimpin berdoa

2) Apersepsi

3) Memimpin pemanasan

b. Kegiatan inti

1) Mengulang gerakan kopstand

2) Penilaian

3. Observasi

a) Mengamati proses pembelajaran

b) Pengisian lembar observasi

c) Mendokumentasikan pembelajaran

4. Refleksi 
Refleksi siklus II digunakan untuk membedakan hasil siklus I dengan siklus II, apakah ada peningkatan partisipasi dan hasil belajar siswa atau tidak. Jika belum ada, maka siklus dapat diulang kembali. Jika ada peningkatan, baik dari proses maupun hasil, maka siklus dapat di hentikan.

\section{Teknik Analisis Data}

Teknis Analisis data dilakukan secara deskriftif (Arikunto, 2010)

$$
\text { Nilai Akhir }=\frac{\text { Jumlah skor yang diperoleh }}{\text { skor total }} \times 100 \%
$$

Setelah dilakukan tindakan pada Siklus I dan Siklus II menunjukan hasil sebagai berikut :

\begin{tabular}{|c|c|c|c|}
\hline No & Nama siswa & Skor tindakan Siklus I & Skor tindakan Siklus II \\
\hline 1. & Aldo Maruanaya & 78 & 78 \\
\hline 2. & Andy Fallen & 81 & 81 \\
\hline 3. & Arnold Rering & 64 & 89 \\
\hline 4. & Berty Salahkory & 81 & 81 \\
\hline 5. & Chelsya Patiasina & 75 & 75 \\
\hline 6. & Dian Latupelle & 53 & 78 \\
\hline 7. & Edgard Simauw & 78 & 78 \\
\hline 8. & Elsa Engko & 67 & 81 \\
\hline 9. & Elton Tuhilatu & 61 & 89 \\
\hline 10. & Edwin Suitella & 78 & 78 \\
\hline 11. & Ester Sabandar & 56 & 78 \\
\hline 12. & Gabriel Sapulette & 67 & 92 \\
\hline 13. & George Pattimukay & 92 & 92 \\
\hline & Gerald Sitanala & 81 & 81 \\
\hline & Gerets Pakaila & 78 & 78 \\
\hline 16. & Holbert Sohilait & 83 & 83 \\
\hline & Jelendia Kayadoe & 58 & 75 \\
\hline & Jemiro Rering & 97 & 97 \\
\hline & Jovanca Pitries & 83 & 83 \\
\hline & Julis Noya & 64 & 92 \\
\hline & Julians Lisapally & 83 & 83 \\
\hline & Kenny Mustamu & 56 & 78 \\
\hline & Kristofol Kolatlena & 78 & 78 \\
\hline & Max Tahapary & 78 & 78 \\
\hline & Jedisa Sorist & 64 & 75 \\
\hline & Maikel Sitanala & 78 & 78 \\
\hline 27. & Paul Sihaya & 78 & 78 \\
\hline & Megy Sahalessy & 61 & 86 \\
\hline & Samuel Putnarubun & 75 & 75 \\
\hline & Geried & 92 & 92 \\
\hline & Jumlah total & 2214 & 2456 \\
\hline Sko & maksimum individu & 100 & 100 \\
\hline & r maksimum kelas & 3000 & 3000 \\
\hline
\end{tabular}


1. Pencapaian hasil belajar siswa kelas $X^{1}$ pada siklus I

$$
=\frac{2214}{3000} \times 100 \%=73,8 \%
$$

2. Pencapaian hasil belajar siswa kelas $X^{1}$ pada siklus II

$$
=\frac{2456}{3000} \times 100 \%=81,86 \%
$$

Dari hasil analisis tersebut dapat disimpulkan bahwa:

1. Terjadi peningkatan hasil belajar setelah diberi tindakan yaitu terjadi $73,8 \%$ menjadi $81,86 \%$ ada kenaikan sebesar $=8,06 \%$

2. Rata-rata siswa sebelum diberi tindakan naik $63,33 \%$ menjadi $100 \%$ ada kenaikan sebesar $=36,67 \%$

Berdasarkan pelaksanaan tindakan maka hasil observasi nilai dapat dikatakan pada pertemuan pertama kegiatan pembelajaran belum berhasil, karena dalam proses belajar mengajar masih terlihat siswa yang bermain, berceritra, dan saling menganggu satu sama yang lain. Penggunaan metode pembelajaran latihan dalam peningkatan prestasi belum tampak, sehingga hasil belajar siswa yang dicapai belum maksimal atau belum tuntas. Proses pembelajaran yang dilakukan dianggap hal yang baru, dan baru mereka laksanakan sehingga siswa merasa kaku dalam melaksanakannya.

Proses pelaksanaan pembelajaran pada siklus II, mereka dapat mengerti dan buktinya proses kegiatan pembelajaran berjalan dengan baik, siswa semua aktif dan mendapatkan hasil yang baik sesuai dengan kriteria ketuntasan yang ditentukan dari sekolah tersebut. Pada siklus I hasil belajar siswa dalam melakukan pembelajaran senam kopstand adalah sebagai berikut: Siswa yang telah mencapai Kriteria Ketuntasan Maksimal adalah 19 siswa dan yang belum tuntas adalah 11 siswa sehingga keberhasilan pada siklus I adalah yang tuntas $63,33 \%$ dan yang belum tuntas adalah $36,66 \%$. Sedangkan hasil belajar siswa pada siklus II adalah sebagai berikut: Siswa yang telah mencapai KKM adalah 30 siswa dan yang di bawah KKM adalah 0 siswa, sehingga keberhasilan pada siklus II adalah $100 \%$ dan siswa yang belum tuntas $0 \%$. Dari siklus I yang presentase ketuntasannya hanya $63.33 \%$ menjadi $100 \%$ berarti ketuntasan hasil belajar siswa mengalami kenaikan sebesar 36,67\%. Demikian dapat dikatakan bahwa pembelajaran telah berhasil karena siswa yang tuntas telah mencapai Nilai KKM.

\section{DAFTAR PUSTASKA}

afif, M. (2019). Penerapan Metode Sorogan Dalam Meningkatkan Baca Kitab Di Pondok Pesantren Tarbiyatun Nasyi'in. Kabilah : Journal Of Social Community, 4(2), 34-43. Https://Doi.Org/10.35127/Kbl.V4i2.3592 Arikunto, S. (2010). Dasar-Dasar Evaluasi Pendidikan. Jakarta: Bumi Aksara. 2010. In Manajemen Penelitian. Daryusman, C., Hermawan, R., \& Adam, U. (2014). Pengaruh Model Pembelajaran Berpasangan Dan Berkelompok Terhadap Keterampilan Gerak Dasar Kayang. Jupe (Jurnal Penjaskesrek).

Fuad, M., \& Sudarso. (2014). Pengaruh Metode Pembelajaran Tutor Sebaya Terhadap Hasil Belajar Dribble 
Sepakbola (Studi Pada Siswa Kelas Viii Smp Negeri 1 Genteng Banyuwangi). Jurnal Pendidikan Olahraga Dan Kesehatan.

Riwu, B. (2003). Kinerja Guru Pendidikan Jasmani Dalam Meningkatkan Prestasi Belajar Siswa Pada Pendidikan Jasmani Olahraga Dan Kesehatan. Prosiding Seminar Nasional Profesionalisme Tenaga Profesi Pjok.

Surlani, I., Musthafa, B., \& Damaianti, V. S. (2019). Penerapan Metode Latihan Terbimbing Bermedia Cerita Bergambar Untuk Meningkatkan Kemampuan Menulis Cerpen Siswa Mts Negeri Jatibarang Indramayu Tahun Pelajaran 2014 - 2015. Jurnal Tuturan. Https://Doi.Org/10.33603/Jt.V8i1.2682

Suyanto, S. (2006). Profil Pranata Sosial Di Daerah Komunitas Adat Terpencil (Studi Kehidupan Sosial Budaya Di Provinsi Nusa Tenggara Timur). Jurnal Penelitian Dan Pengembangan Kesejahteraan Sosial.

Winkel, W. S. (1996). Psikologi Pengajaran. Grasindo.

Wuryantoro, K., \& Muktiani, N. R. (2011). Meningkatkan Keterampilan Senam Meroda Melalui Permainan Tali Pada Siswa Kelas Viiia Mts Ma ' Arif Nu. Jurnal Pendidikan Jasmani Indonesia. 